\title{
SURFING THE NEW WAVE: \\ INTERNATIONAL WOMEN'S YEAR AND \\ THE GEOPOLITICS OF 1970s MEXICAN FEMINISM ${ }^{1}$
}

\author{
SURFEANDO LA NUEVA OLA: \\ AÑO INTERNACIONAL DE LA MUJER Y GEOPOLITICA \\ DEL FEMINISMO MEXICANO
}

\section{Jocelyn Olcott \\ Duke University \\ United States \\ olcott@duke.edu}

\begin{abstract}
Although scholars and activists point to the 1975 International Women's Year Conference as a pivotal moment in the development of transnational feminist networks, there has been less attention paid to the importance of its taking place in Mexico City. This article explores how the "new wave" of Mexican feminism in the early 1970 s shaped policy priorities within Mexico as well as how the geopolitical context informed the range of possibilities open to feminist activists. As Mexican President Luis Echeverria pursued recognition on the international stage, he sought to align Mexican policies with UN priorities around population control and women's opportunities.
\end{abstract}

Keywords: Geopolitics, International Women's Year, Mexican feminism, Transnational feminism, United Nations.

\section{Resumen}

Aunque investigadores y activistas consideran la Conferencia del Año Internacional de la Mujer de 1975 como un momento crucial en el desarrollo de redes de feminismo transnacional, se le ha prestado menos atención por haberse celebrado en Ciudad de México. Este artículo explora cómo es que la "nueva ola" del feminismo mexicano de los setenta definió prioridades políticas en México, así como su contexto geopolítico. Mientras el presidente Luis Echeverría buscaba reconocimiento en el escenario internacional, buscó alinear las políticas mexicanas con las prioridades de las Naciones Unidas en torno al control poblacional y las oportunidades de las mujeres.

Palabras clave: geopolítica, Año Internacional de la Mujer, feminismo mexicano, feminismo transnacional, Naciones Unidas.

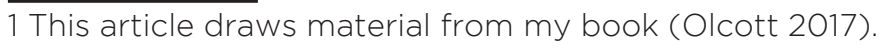


In mid-June 1975, thousands of people poured into Mexico City for the world conference honoring International Women's Year (IWY) -the first of four UN women's conferences and an event that turned out to be a game changer both for transnational women's organizing and for the United Nations itself. While scholars have tended to write about IWY's transnational impacts, the conference also shaped and was in crucial ways shaped by the so-called nueva ola of Mexican feminism. The conference itself as well as all the ancillary events provided a stage -often quite literally- for politicians and activists alike to perform their ideological convictions for audiences at home and abroad. In particular, the conference demonstrated the imbrication of feminism with geopolitics: how feminist activism shaped policy priorities and how the geopolitical context created openings and defined the possibilities for progress on feminist priorities.

\section{Mexico City: Showcase of Developmentalism}

Mexico City itself played an important role in giving meaning to the IWY events. By the mid-1970s, the United Nations already considered Mexico City one of the world's three "mega-cities" along with Tokyo and New York (Ward, 2013 [1981]: 36; Davis, 1994). Pollution was already considered a crisis. The metropolitan area had mushroomed over the previous three decades and sprawled into the surrounding suburbs. Squatter communities sprouted virtually overnight; the municipality of Ciudad $\mathrm{Ne}$ zahualcóyotl had grown from a population of roughly 40,000 in 1964 to nearly 2 miIlion by 1975 . The Mexico City metropolitan area had grown from nearly 3.4 million inhabitants in 1950 to over 10.7 million by 1975 (UN, 2019). This dramatic population growth mostly stemmed from rural-urban migration as modernization programs drew people from agricultural to industrial production.

Like the 1968 Olympics, the 1975 International Women's Year conference was inten- ded to showcase Mexico City as evidence of the nation's strides toward modernization and capacity for geopolitical leadership (Castañeda, 2014). The conference centered in two iconic locales: Tlatelolco Plaza in the north and the new Medical Center to the south. The official UN gathering of delegations representing member states took place at the Secretaría de Relaciones Exteriores on Tlatelolco Plaza, which had hosted the signing of the 1967 nuclear non-proliferation treaty but is, of course, more often remembered as the site of the notorious 1968 student massacre. Five kilometers to the south, the Centro Médico (1964), the icon of Mexico's modern welfare state, hosted the nongovernmental (NGO) gathering -what the New York Times dubbed the "scene of much shouting, scheming, plotting, and general hell- raising" (Klemesrud, 1975a: 2).

The Mexico City metro system -then one of the world's most modern- stretched directly from Tlatelolco to Hospital General, about a half mile north of Centro Médico, but travel by metro required a ten-minute walk at either end, often under soaking summer rains, and, as one participant explained, required one to "drop all dignity and wrestle the crowds for a place". ${ }^{2}$ Delegates and activists participating in both the government and NGO forums instead spent ages stalled in traffic on the north-south axis of Insurgentes. As Australian feminist Germaine Greer quipped:

The delegates spent one third of their waking hours imprisoned in their official cars, glumly wondering if their mental stupor was another effect of the altitude or how long they could hold out in the endless traffic jams before setting off on foot in search of a toilet. The virulent Mexican version of tourist tummy laid low some of every delegation all of the time. The fourteen hotels which housed the delegates roared like Niagaras as they strained the plumbing to the utmost (Greer, 1986: 199).

2 Lucile Schuck to Bob [Robert Brown], July 4, 1975; Arthur and Elizabeth Schlesinger Library on the History of Women, Lucile K. S. Longview Papers, Box 2, Folder 2. Line 3 of the Metro would not extend to Centro Médico until 1980. 
Mexico City's altitude and smog only made matters worse.

But why was an International Women's Year conference in Mexico City in the first place? To many feminists, holding a women's conference in the machista environment of Mexico made about as much sense as holding the UN's 1968 human rights conference in Teheran, under the shah's notorious repression. One US feminist, warning about the Mexican government's propensity for violent repression wrote in a newsletter, "Firstly, Mexico City is the most chauvinistic 'macho' city around, and it seems paradoxical why the event should be held there. Perhaps it's a set up by the CIA, FBI, etc." (OAC, 1975: 11). Judy Klemesrud, reporting for the New York Times, noted: "Many people find it ironic that the first world conference on women's rights should be held in one of the world's most macho capitals, Mexico City" (Klemesrud, 1975b: 7). Reflecting after the conference closed, Newsweek magazine reported: "It seemed like a male-chauvinist joke -holding the first major international conference on women in a stronghold of macho, Mexico City" (Anonymous, 1975a: 28). The Mexican press got in on the act, too. The cartoonist Sergio Iracheta penned a satirical column in El Universal, alongside a cartoon of woman in low-cut tank top and flowered pants carrying sign with the IWY logo captioned "IGUALDAD", accompanied by a mustachioed man in a suit and sunglasses smiling and clapping while his shadow wears a cowboy hat and shakes his fist in the air, fuming and cursing.

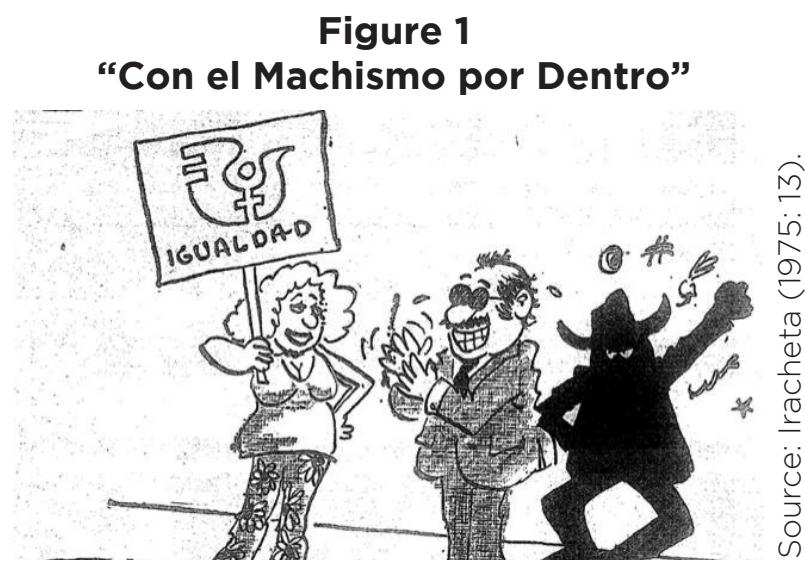

"The mexicanísimo machismo has suffered a rude blow", he chided:

and to make matters worse (for the machos of course), the World Conference for International Women's Year had to be celebrated exactly here in Mexico. Here where generations and generations of machos have been raised and nourished on the films of Jorge Infante and Pedro Negrete [sic], here where the machismo has been built upon the foundation of the traditional abnegation of the madrecita Mexicana (Iracheta, 1975: 13).

The conference took place in Mexico City not because the Mexican government had had a feminist awakening nor even because of the burgeoning Mexican women's movement but rather because President Luis Echeverría badly wanted to become secretary-general of the United Nations. His sexenio would end in 1976, and he openly jockeyed to position himself as leader of the third-worldist Non-Aligned Movement that had recently gained control of the UN General Assembly. In 1974, he spearheaded the UN's adoption of the Charter on the Economic Rights and Duties of States -a codification of national economic sovereignty that his supporters dubbed the Carta Echeverría. ${ }^{3}$ When plans to hold the Internatio-

$\overline{3}$ The Charter on the Rights and Duties of States created a UN framework for implementing the non-aligned-supported New International Economic Order, calling for economy sovereignty over natural resources. The PRI Congresswoman Aurora Navia Millán explained to a reporter from El Universal, "The solution to the problem [of economic exploitation] is in the hands of everyone [...] it is in the Carta de Echeverría that was approved with the majority of votes in the United Nations" (Valadez, 1975: 9). The CIA reported, "The Charter of Economic Rights and Duties of States was proposed in the May 1972 session of the United Nations Conference on Trade and Development. UNCTAD then created a 40-member working group, to 'establish generally accepted norms to govern international economic relations,' which drafted the Charter. Mexico's President Echeverria became closeIy identified with the Charter and accepted its approval as a personal victory in his campaign to extend his influence as an LDC [less-developed country] leader. Considering the sharp rivalries among LDC leaders, it is not surprising that some other LDC spokesmen have unofficially expressed ambivalence towards the Charter and Mexico's position in the movement" (InteIligence Memorandum Prepared in the Central Intelli- 
nal Women's Year conference in Bogotá fell through, Mexico's UN ambassador volunteered with alacrity to host it in Mexico City. By the mid 1970s, women's rights had emerged as an area where progressive governments tried to position themselves at the vanguard, and Echeverría doubtless anticipated that hosting a women's conference -in Tlatelolco Plaza, no less- would not only whitewash his involvement in violent state repression but also secure a place in the spotlight of international politics.

\section{Cosmopolitan Nationalists: Casting Characters and Performing Politics}

The opportunity to demonstrate leadership on the world stage led the Echeverría administration to highlight the ways that Mexico's foreign and domestic policy dovetailed with the UN's own priorities regarding issues such as population control and women's rights. Deploying a characteristically presidentialist approach, he put the attorney general Pedro Ojeda Paullada in charge of the year and demanded that every governor report on how his state had addressed concerns about women's status. ${ }^{4}$ He opened a well-staffed program office in Mexico City that, among other things, published a glossy-full cover magazine, the first issue of which sported a cover dominated by a three-quarters profile torso shot looking up at a smiling Echeverría (Anonymous, 1975b: 1). In March 1974, six months before the UN's first Population Conference in Bucharest, Echeverría created the Consejo Nacional de Población (Conapo). Immediately after the UN relocated the IWY conference from Bogotá to Mexico City, he pushed through Congress a constitutional amendment to grant women equal rights (Connelly, 2008). Since December 1974, the fourth article of the Mexican constitution begins, "Man and

gence Agency, Washington, February 11, 1975; Foreign Relations of the United States, 1969-76, Vol. E-14, Part I, Doc. 20.)

4 Letter from Lic. Mario Moya Palencia, 26 October 1975, Archivo General de la Nación (AGN), Dirección Federal de Seguridad (DFS), Exp. 44-1-74, Leg. 5, Hoja 241-242. woman are equal before the law. This will protect the organization and development of the family" (Toto Gutiérrez, 2002). It goes on to guarantee the "right to decide in a free, responsible, and informed manner the number and spacing of children". It establishes the right to health care and underscores the government's responsibility for providing health services, the guarantee of a "dignified and decorous living," and parents' responsibility to "preserve the rights of minors regarding the satisfaction of their needs and their physical and mental health". Mexico's juridically positive postrevolutionary constitution emphasizes obligations rather than restraints on the federal government, and this amendment underscores the Echeverría administration's efforts to hew to UN priorities of population control and social development.

Importantly, the constitutional amendment also took up core demands of the feminist movement -to wit, reproductive freedom and juridical equality- but put them in the framework of protecting the sanctity of Mexican families. In other words, feminist concerns that the state would co-opt its agenda were well founded, but they reveal the complex relationship between activism and institutional politics. If feminists could achieve their most pressing demands with a relatively modest amount of pressure, perhaps they should -like many of their comrades from the ' 68 generation- throw in their lot with the ruling party. Indeed, the question of how and whether to collaborate with government programs emerged as one of the most vexing and divisive issues as feminists deliberated over how to respond to IWY.

When leading Mexican feminists learned in November 1974 that an international women's conference would take place in Mexico City the following summer, they were outraged. Much as the civil-rights movement had fostered a dominant strain of U.S. feminism, the nueva ola of Mexican feminism grew out of the struggles and frustrations of Mexico's 1968 student movement; feminist leaders bore the scars of the Tlatelolco 
massacre, and the 1971 Corpus Christi massacre had been like salt in the wound. The idea that President Echeverría -whom most Mexicans held responsible for both tragedies- would burnish his international image by holding himself up as an advocate of women's rights seemed like a blatant attempt to co-opt and defang the feminist movement. Holding the official conference at Tlatelolco Plaza only added insult to injury.

This "new wave" of Mexican feminism and urban, middle-class movement dominated by intellectuals- had a cosmopolitan streak from the start, taking on its inchoate institutional formation in 1971 with the formation of Mujeres en Acción Solidaria (MAS) under the leadership of Marta Acevedo, a leader during the 1968 movement and witness to the Tlatelolco massacre (Lau Jaiven, 1987). Acevedo credited her own feminist awakening to her experiences with feminist consciousness-raising groups in Berkeley and San Francisco, California, in 1970 and, a few years later, with the writings from the Wages for Housework movement in Italy (Acevedo, 2000, 1971; Lau Jaiven, 2000: 14; Lamas, 2002: 72). Several leading feminists, including Marta Lamas, recall meeting the charismatic Acevedo after Susan Sontag delivered a lecture in late 1971 in the UNAM Political Science faculty, the headquarters of the '68 student movement (Lamas, 1996: 8; López Vega, 2011). As Lamas recalls, when a minority group within MAS accused the majority of being "insufficiently Marxist", the majority broke off and formed the Women's Liberation Movement, a name chosen because it "identified us with that international current" (Lamas, 1996: 9). This cosmopolitan aspect of the movement -combined with the internationalist influence of the communist and Trotskyist groups that loomed large within these circles- engendered a deep suspicion of official politics, of the ruling party, and of Echeverría in particular.

Mexico City had served as a hub of cosmopolitan nationalism for roughly a century (Tenorio Trillo, 2012). It had long provided refuge for political exiles from throughout the Spanish-speaking world, drawing Spanish Republican exiles from Franco's bloody regime in the 1930s. In 1975, many Chileans fled to Mexico City after the Pinochet coup, joining those escaping other military dictatorships (Yankelevich, 2002). This left-leaning cosmopolitan exile community would also contribute to the nueva ola; émigrées such as the Guatemalan poet and activist Alaíde Foppa, the journalist Elena Poniatowska served among founding editors of the feminist magazine fem. In addition to having contact with feminist intellectuals and exiles in Mexico City, many women who led the new-wave organizations had lived or studied abroad, in places like London, Paris and Barcelona, where they came into contact with new feminist ideas (such as the wages-for-housework campaign), feminist practices (such as consciousness-raising groups), and feminist subjectivities (such as lesbianism). In the published recollections that appeared in Mexico's feminist press, one woman after another links her formation of feminist consciousness to a transformational encounter with ideas from outside Mexico. ${ }^{5}$

For all its cosmopolitanism, however, many characteristics marked this feminism as distinctly Mexican. First, it replicated many of the sectarian splits that fractured the Mexican left in the 1970s (Illades, 2013). Second, the government's willingness to use repressive force intimidated activists from demonstrating openly; women attended meetings but then shied away from participation in public demonstrations. As Marta Lamas recalls, when the newly formed MAS decided to hold a march on Mother's Day in May 1971, "this decision to take to the street cost the incipient MAS two-thirds of its membership. The fear of demonstrating was well founded, since no group had attempted it after the bloody events of 10 June 1970" (Lamas, 1996: 8). Third, many US and European feminists' core demands did not resonate with their Mexican counter-

\footnotetext{
5 The citations would be too many to list, but these recollections appear in magazines such as fem, Debate Feminista and La Correa Feminista.
} 
parts. While US feminists struggled for the passage of the Equal Rights Amendment, Echeverría effectively had decreed one by fiat. While US and European feminists debated the merits of demanding wages for housework, Mexican feminists generally paid someone else to perform this labor, creating what novelist Rosario Castellanos described as a cushion -un colchoncito- that insulated Mexican women from the structural contradictions that animated feminist movements elsewhere (Lau Jaiven, 2000: 15; Acevedo, 2000; Collectif de femmes d'Amérique latine et de la Caraïbe, 1977: 83-99; Larguía, 1972). As Castellanos wrote, "When the last servant (la última criada), the cushion on which our conformity now rests, has disappeared, there will appear the first furious rebel" (Excélsior, March 5, 1970; quoted in Ludec, 1999: 283). Finally, the government's eagerness to co-opt feminism confronted activists with a textbook quandary of co-optative regimes: whether to accept government support or to reject it and retain their autonomy.

\section{Infrastructures of Activism: Program- ming and Counter-Programming}

The IWY conference and attendant programming galvanized feminist activists on both sides of this divide to dedicate time, energy and resources to take advantage of this national and international attention to feminist concerns. The level of state support raised the stakes of opting out of the official program. As Esperanza Brito de Martí, the leader of the Movimiento Nacional de Mujeres later recalled:

At the end of 1974, Lic. Pedro Ojeda Paullada [Procurador General de la República], in his role as General Coordinator of International Women's Year, convened us, as with all the groups, to chat, get to know our projects, and, if possible, to incorporate them into the Official Program. We were ready to carry out, under the leadership of Luz Elena Picos, a cycle of conferences that would take place in 12 of the 16 delegations of the Distrito Federal. Only in
12 because four delegates did not accept our presence. The dates had already been agreed upon with the 12 delegates; that is to say, we were ready to start. In a very gentle manner, we were informed that we would only be able to carry out the project if we were incorporated into the Official Program, and thus our group's activity started, in January 1975, as the Official Program of the International Women's Year (Brito de Martí, 1996: 17).

Once the group signed on, the funding came pouring in, amounting to support for 144 conferences during the course of the year. The group's collaboration came with a price tag, however. Brito recalled:

During these first years of our group's existence, we were rejected and discriminated against by members of other feminist groups. There was an enormous distrust among the groups, and this translated into the total dissolution of the movement. They accused us of being members of the PRI, which we never were, of being petty bourgeois because we didn't wear jeans, and of being reformist because we wanted to change the laws (Brito de Martí, 1996: 17).

For her part, Marta Lamas remembers 1975 as an exhausting year as dissident feminist activists struggled to keep pace with official programming (Lamas, 1996: 10). As the historian Ana Lau Jaiven recounts, seeing the UN and Mexican state projects as a "lukewarm and opportunistic appropriation of feminist proposals", a committed group of feminists formed the Women's Front against International Women's Year (Lau Jaiven, 2000: 20-21; Acevedo, 2000: 63). Taking advantage of the spotlight cast by the official propaganda, the group traveled all over the country convening conferences, presenting street theater, organizing movie clubs, planning solidarity actions with female wage workers, meeting with feminists from various countries, and passing out flyers everywhere they could. Citing the official IWY themes of equality, development, and peace, the flyers proclaimed, "We do 
not want equality of conditions to be exploited in the same way as men; we do not want development that perpetuates economic, racial, and sexual inequalities; we do not want peace that only signifies the stability of the current system" (Lamas, 1996: 10). In an interview years later, Berta Hiriart describing herself as a theater type and "not very political", remembers that she had gone with a group of friends to stage some street theater outside the government conference. After that, she recalls, "some of the women from the group were hooked by the feminist movement. We began to go to the meetings, we began to learn a lot of things, we began to read" (Caulier, 2014: 72; Hiriart, 2002: $56-60){ }^{6}$

As would become increasingly evident in the decade that followed, the Mexican ruling party's strategy of cooptation and incorporation had begun to fray, and the Echeverría government grew increasingly anxious at the prospect of thousands of civil-society activists coming to Mexico City and stirring up trouble. As an Iranian UN mission member recalled later in an oral history, "In those days, member states were worried about NGOs being radical revolutionaries; the idea that they might be cooperative was not seen as an option; they were viewed more like rabble-rousers" (Walsh, 2012: 9). Aída González Martínez at the Mexican Ministry of Foreign Relations implored the US State Department to limit the number of activists coming to Mexico, particularly what she saw as "radical elements" such as US feminist Betty Friedan.

Perhaps nothing so perfectly captured the Mexican government's flagging capacity to control civil society -along with the political theater of the IWY events- as the conference inauguration. Participants filed into the Juan de la Barrera stadium, a facility built for the 1968 Olympics and named after one of the apocryphal Niños Héroes who was supposed to have jumped to his death during the US occupation of Mexico in 1847. People up in the cheap seats fanned

6 Interview with Berta Hiriart by Mathieu Caulier, February 2007, in possession of author. themselves while high-level diplomats took their assigned places on the floor seating, following elaborate protocols. As Secretary-General Kurt Waldheim delivered his inaugural speech, he was interrupted by the chants of protesters outside the building. The Movimiento Juvenil Mexicano and Solidaridad con Chile distributed flyers protesting the Pinochet regime, and the Spanish Women's Liberation Movement agitated to demand the liberation of women political prisoners ( $A G N, 1975 b$ ). The demonstrators also included a caravan of roughly 200 women wearing threadbare, rural clothes who marched barefoot under the banner of the Movimiento de Mujeres Margarita Maza de Juárez, carrying signs with slogans such as "Plan your family", "Mexico welcomes you", and "Discrimination against Third World women must end".

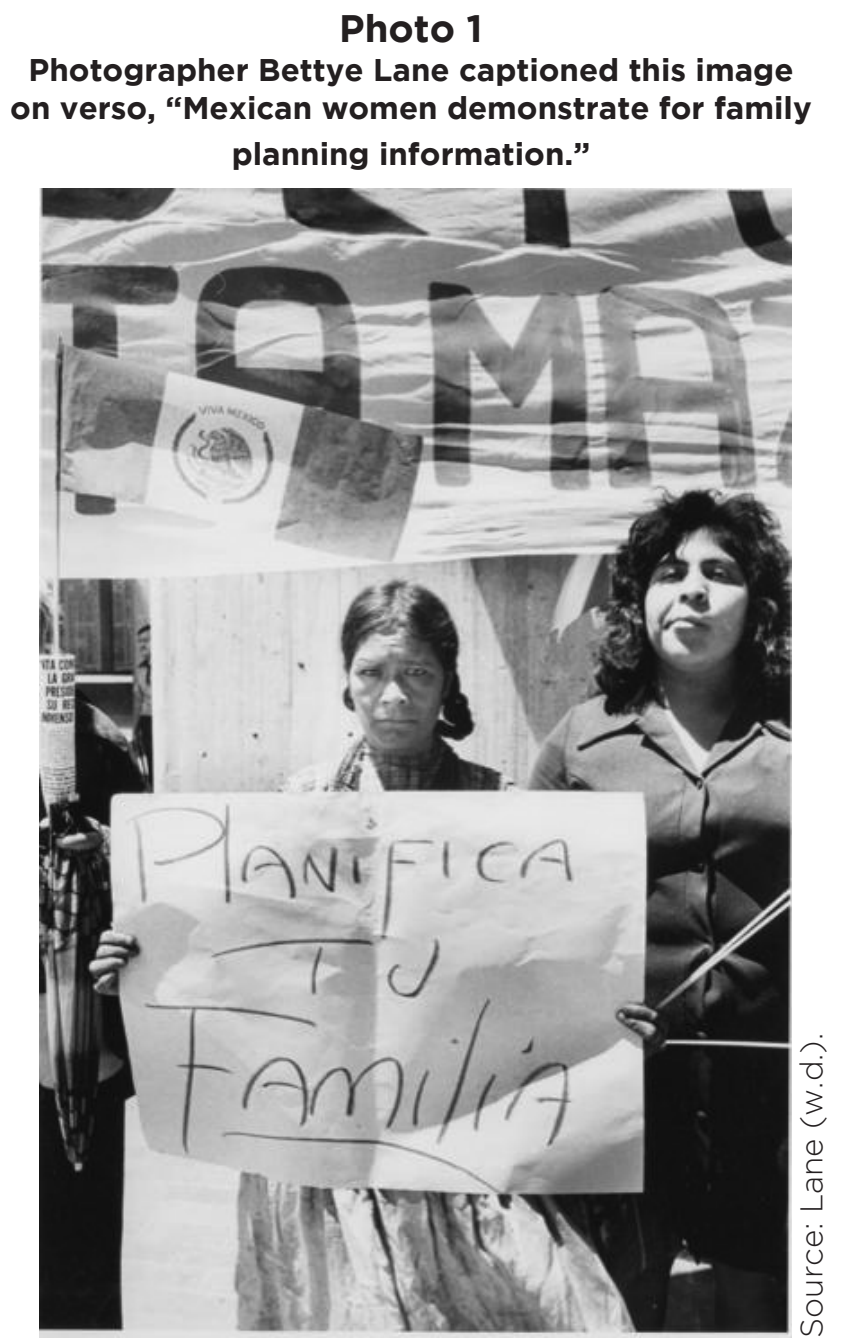


Although some observers, including the renowned photographer Bettye Lane, took the demonstration at face value, many IWY participants and even security forces described the group as a shell organization of women who had been bused in for the event (and paid for their troubles) and that existed only to create the illusion of popular support for the Echeverría government and the conference (Friedan, 1998: 442). ${ }^{7}$

As the newspaper Excélsior reported, "The demonstrators, who were obliged to leave their market stalls in the Vallejo neighborhood to shout cheers of welcome to the visiting delegates, protested because they had been left in the street with banners and signs, under the inclement sun" (Anonymous, 1975c, 1-A, 20-A; see also Greer, 1986: 200). The women gathered outside the massive glass doors until they numbered enough to force their way in, sending police officers scurrying to secure the sliding doors that allowed entry to the central arena.

As Waldheim spoke from the podium, they reached the periphery of the audience and shouted, "We, too, are women!". Journalists ran from door to door, ignoring Waldheim's speech as they tried to ascertain what was happening, security agents shoved the demonstrators out of the arena, and the women "unleashed an intense clamor of insults" as audience members attempted to discern the cause of the ruckus. The incident captured not only how little control the government exercised over even its paid supporters but also the difficulty of distinguishing political shenanigans from authentic political expression.

\footnotetext{
7 It is possible - both because of the signs the women carried during this episode and because the DFS seemed quite suspicious of the group - that they were organized (and perhaps paid) by the Communist Party-affiliated Unión Nacional de Mujeres Mexicanas (UNMM, an affiliate of the Federación Democrática Internacional de Mujeres), whose president, Martha López Portillo de Tamayo, and her husband had a particular fascination with Benito Juárez and his wife Margarita Maza de Juárez (see also AGN, 1975c y 1975d).
}

\section{Translation Challenges of Political Theater}

The demonstration outside Juan de la Barrera stadium was not the only irruption at the IWY events, nor was it the only episode in which observers offered starkly different readings of the political theater they witnessed. Fault lines emerged as soon as the intergovernmental conference and NGO tribune got underway, with some of the rancor resulted from mutual illegibility of these political performances. Betty Friedan provoked an outcry when she threatened to march up the Avenida de la Reforma to protest Ojeda Paullada's election as conference president. While some pointed out that his election simply followed UN protocols and others argued that it would benefit the cause of women's rights to have men take more interest, some stressed that their protest should focus not on his sex but rather his reputation for repression.

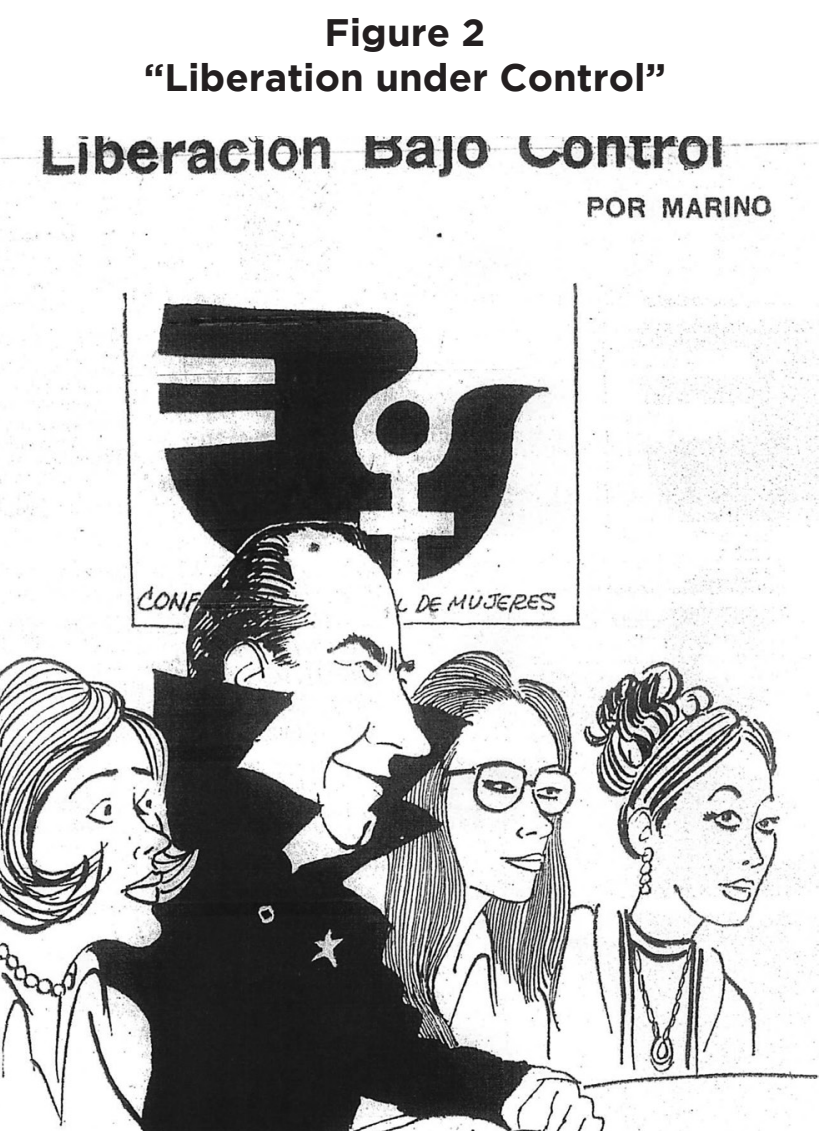

Source: Marino (1975: 6-A). 
Friedan and others further antagonized fellow attendees when they arrogated to themselves the right to represent the NGO tribune to the governmental conference, presuming to speak for an authentic feminism (Olcott, 2017).

\section{Figure 3 "Modern Ideas"}

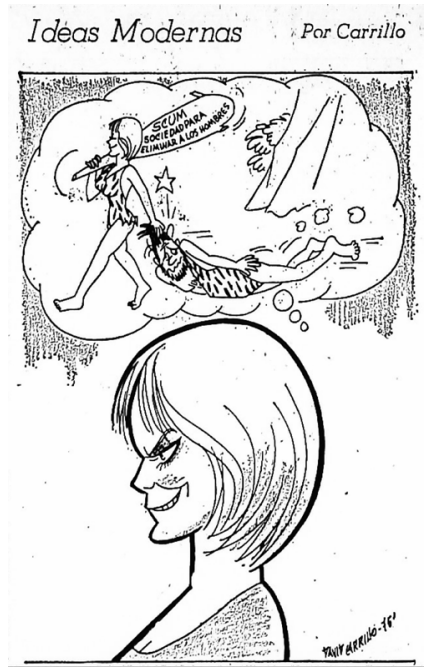

Source: Carrillo (1975: 5).

The Mexican press responded with an attack on US feminism as an imperialist import, expressing particular alarm about SCUM, referring to Valeria Solanas's satirical proposal for radical feminism. ${ }^{8}$ In the apparent belief that the SCUM Manifesto spoke for an actual, existing organization, El Universal editorialized:

This newspaper became aware yesterday of this strange feminist body, apparently formed in the United States, and, not least because of its originality, cannot refrain commenting [...] As humor, it can pass; as a feminist organization that is supposed to be serious and worthy of respect, it is controversial to say the least (Anonymous, 1975d: 5).

Perhaps someone informed the editorial board that SCUM was not an organization

8 Solanas self-published S.C.U.M. Manifesto in 1967. The first commercially published edition appeared the following year as (Solanas, 1968). Solanas is most notorious for 1968 attempt to murder the artist Andy Warhol. but merely a figment of Solanas's very active imagination. The following day, the journalist Miguel Bueno wrote an editorial the explaining that SCUM was "not a very broad" organization but insisting that it was no joke but rather a serious warning about the threat of extremist feminism (Bueno, 1975: 4). ${ }^{9}$

At the NGO tribune, participants coalesced into two factions: the United Women of the Tribune (led by US feminist Betty Friedan and the Mexican feminist Esperanza Brito de Martí) and the Women against Imperialism (for whom the Bolivian militant Domitila Barrios de Chungara emerged as a standard-bearer)..$^{10}$ Some demands were common across these groups: reproductive freedom, juridical equality, political representation, and an end to the commercial objectification of women. But the Marxist group stressed concerns that the feminists either had not considered or dismissed as too "political," such as protection for migrant workers, socialization of reproductive labors, freedom for political prisoners, and social security for rural women." As tensions mounted between and within the caucuses -and participants argued over where the dividing line lay between politics and women's issues or whether such a division existed at all- another fault line appeared. An Australian student named Laurie Bebbington stood up, "amid whistles and jeering," and nervously read from a prepared text she had titled "Lesbian Speech".

Sexuality per se had not been on any official agenda in Mexico City, apart from passing attention to the often-conflated issues of prostitution and trafficking and the nearly obsessive concern with fertility and population control. Questions about pleasure and desire and even sexual identification only fueled concerns that the UN operated

9 It is worth remembering that concerns about "extremism" ran high in Mexico in the mid-1970s. Just a year earlier, Echeverría's father-in-law had been abducted the summer before, and left-wing guerrillas and paramilitary groups had escalated violence over the late 1960 s and early '70s. See, for example, Cedillo and Calderón (2012).

10 See AGN, 1975c.

11 For a list of the groups demands, see AGN w.d. 
as a vehicle for cultural imperialism that sought to impose Western models of family formation and sex roles, acting as a Trojan horse that smuggled in unacceptable sexual freedoms. The Mexico City daily Excélsior cautioned in its lead editorial about the conference inauguration:

The Conference of International Women's Year that begins today, in which women's liberation will be debated, is important. Nevertheless, this should be understood as the full development of women and not in the distorted form of loveless sexual debauchery, as reproachable in men as in women, since it promotes the moral degeneration of everyone (Anonymous, 1975e: 6-A).

Bebbington had not been the first lesbian to speak out at the NGO tribune. Frances Doughty, a leader of the National Gay Task Force in the United States, had spoken up during one of the very first sessions, expressing her desire to share ideas with other lesbians (Meléndez, 1975; Berdejo, 1975: 10; Anonymous, 1975f : 12; Bunch and Doughty, 1975: 6). Over the weekend between Doughty's intervention and Bebbington's, they had gotten organized, dubbing themselves the International Lesbian-Feminist Caucus (Doughty, 1978: 145). On Monday, Doughty stood up with Bebbington as she set off a firestorm during a session on socialization and cultural attitudes and rejected compulsory marriage and motherhood and describing heterosexuality as a "form of cultural imperialism". Bebbington's insistence on women's liberation from men and from obligatory maternity seemed to alarm the media even more than her open sexuality (see coverage of Bebbington's speech [all on 24 June 1975] in El Universal, Excélsior, Novedades, Diario de México, El Nacional; Fuentes, 2014). Upon finishing her speech, Bebbington was surrounded by women sporting "radicalesbians" t-shirts, who showered her with hugs and kisses. Some audience members cheered; others booed; a few simply walked out.
It was this last group that got the attention of the prominent theater director Nancy Cárdenas. Like many other feminist activists of the early 1970s, Cárdenas was a veteran of the ' 68 protests and had lived and studied abroad, at Yale University in the United States and then in Lodz, Poland. She was also without question Mexico's most prominent lesbian. A founder of the Mexico's first openly gay organization, the Frente de Liberación Homosexual, Cárdenas had publicly proclaimed herself a lesbian the year before on the nationally televised talk show, Jacobo Zabludovsky's 24 Horas. After the Monday panel where Bebbington first spoke out, some "visiting lesbians" urged Cárdenas to participate in the following day's forum on lesbianism:

They told me that the Communists, my own compañeras from earlier in the party, abandoned the conference hall when an Australian girl said "I'm a lesbian feminist", she recalled later in an interview. They said, "Throw out the sickos, we're out of here". That seemed to me to give an incomplete image of Mexico, because I was also a leftist militant, was a lesbian, and I had another position and raised my finger (Mogrovejo, 2000: 67).

Inspired by what she deemed the "guerrilla model of the US women's liberation movement", Cárdenas had acceded to the visitors' request for her support. An estimated 250 women looked on as Cárdenas presented the Declaración de las lesbianas mexicanas, pointing to sexual recognition as a critical form of social liberation. "We trust [...] that the tactics of struggle used by our brothers and sisters in other parts of the world will help us to find our own path". ${ }^{2}$

\footnotetext{
12 Laurie Bebbington sent a copy of the declaration to Elizabeth Reid saying it had been anonymously delivered to Frances Doughty, who distributed it to the press and the tribune (Elizabeth Reid papers, Australian National University, folder 87). Claudia Hinojosa attributes the unsigned Declaración de las lesbianas de México to Cárdenas, insisting that one can recognize the "unmistakable prose of a luminous spokeswoman of Mexican lesbians, the beloved and eternal Nancy Cárdenas" (Hinojosa, 2001: 179).
} 
Despite feminist protests to the contrary, both the Mexican press and the Marxist left persistently framed a zero-sum tradeoff between sexual rights and human rights (Wilson, 2002). This Manichean reading ascribed meaning to every political performance, forcing participants to demonstrate their political bona fides to their ideological allies while deepening the purported divide between the two camps. The lesbian forum where Cárdenas spoke vacated the meeting room in time for it to be used by a group calling itself "Mujeres Demócratas Chilenas". The audience had listened in stunned and respectful silence as three women recounted their experiences of detention and torture under Pinochet. Afterwards, a coalition of left-leaning organizations invited attendees to a counter-conference at the Hidalgo Theater on Mexico City's historic Alameda Central, to prevent "the themes of lesbianism and prostitution distracting from questions of importance and transcendence" (AGN, 1975e).

Roughly, a thousand people gathered for this anti-Pinochet rally featuring speeches by communist leaders such as the Soviet cosmonaut Valentina Tereshkova, the Cuban revolutionary Vilma Espín, and Salvador Allende's widow, Hortensia Bussi de Allende, punctuated by chants of "El pueblo unido jamás sera vencido" and ending with a rousing chorus of the International ( $A G N$, 1975f).

Simultaneously, a group of young leftists from the Movimiento Liberación de la Mujer, Grupo Leninista Feminil, the Liga Socialista, and a Communist student organization Grupo Comunista Internacionalista staged another demonstration across town in the Casa del Lago, the UNAM-run cultural center in Mexico City's picturesque Bosque de Chapultepec (AGN, 1975g, 1975h y 1975i). Activists would have had to choose whether to join the anti-Pinochet rally or to join the 700 or so young people demanding twenty-fourhour childcare facilities, collective kitchens and laundries, the socialization of housework through a domestic wage, and -above allfree and legal access to abortion. The Mexi- can press was unsparing in its comparison of these two demonstrations. In contrast to its reverent article about the anti-Pinochet rally, El Universal's article about the student demonstration stressed only their youth and inexperience, depicting them as children playing revolutionary games. "Beneath a benign sun, girls [niñas] -their voices as sharp as their proposals were radical-spoke of the exploitation of women in the capitalist system and the need to unite with the proletarian struggle", the paper reported. The article mocked the students' ratty jeans - "worn with pride because there is no more revolutionary touch than a 'humble' outfit"- as well as their speeches. Describing the protesters as "false-sounding" and "as insipid as they were ill-informed", the El Universal reporter sneered:

\begin{abstract}
The youngsters [jovencitas], trying to give a grandiose tone to their discourse, with so little originality given their canned and dogmatic repetition and insistence on philosophical concepts that have become linguistic jargon, took a stand for the "socialization of domestic labor". Saying that staging a revolution every Sunday had become a fad at Casa del Lago, the article concluded dismissively that "the representatives of feminist organizations so few that they seem spectral" had staged a "festival in which the disoriented nonconformists let loose with their urban hysteria" (Anonymous, 1975g: 10).
\end{abstract}

A few days later, international crowds dissipated just as they had arrived. Attorney General Ojeda Paullada dropped the final gavel on the intergovernmental conference, proclaiming it a triumph despite deep divisions over Zionism and a refusal to include "sexism" among the obstacles to women's emancipation. At the NGO tribune, a mariachi band struck up, giving a celebratory feel to the closing session while also drowning out a group of rural women from Guerrero who attempted to denounce military repression in their communities (AGN, 1975j). 


\section{Epilogue: The Geopolitics of Mexican Feminism after IWY}

The IWY conference marked a pivotal moment for many national feminist movements, as it would in Mexico, not least because it fostered an infrastructure of normative conventions and expectations that have allowed women to make demands on their home governments, even as they often remain deeply suspicious of the UN itself. It also transformed debates and dynamics within feminist movements, as it clarified their dynamics and priorities. Starting in 1981, the "Encuentros Feministas Latinomericanos y del Caribe" have gathered every few years in locations throughout Latin America to deliberate about the meanings, priorities, and strategies of the region's feminist movements, often orienting their agendas toward shaping the agendas as thematic UN meetings not only around women's issues but also questions such as population and environmental concerns. Mexican feminist activism retained its strong cosmopolitan flavor and its ambivalent relationship with Mexico's Marxist left, but IWY did leave at least three important legacies.

First, the events of the NGO tribune called the question on where lesbians fit into Mexican feminism (Mogrovejo, 2000: Chapter Two). As activist Claudia Hinojosa recalled later, "It's true that nobody anticipated that this conference would be converted into the forum for the first public discussion of lesbianism in Mexico. I remember that I observed all those incidents, surprised and confused, from the darkest corners of the closet" (Hinojosa, 2001: 179). After the conference, feminist activists attempted to form a coalition, but an influential Marxist organization, the Unión Nacional de Mujeres Mexicanas, pulled out when two open lesbian groups joined (Lau Jaivén, 2014). After 1975, however, it had become impossible to ignore the critical role that lesbian feminists had played in feminist organizing; sociologist Sylvia Marcos indicates that by 1976 three issues defined Mexican feminism: insistence on reproductive freedom, the struggle against gender violence, and the fight for lesbian and gay rights (Marcos, 1999: 431).

Second, the conference demonstrated the powerful role of mass media in ascribing meanings to social movements. Many feminist leaders concluded that they should concentrate their energies on producing feminist publications (Olcott, 2012). Elena Urrutia, one of the founding editors of the magazine fem, recalled:

It was the middle of the seventies, and a smaIl group of us had already spent a few years publishing our feminist reflections, denunciations, and criticisms in the means of dissemination within our reach: some in newspapers and magazines, some in radio and eventuaIly television, some in the professoriate. The United Nations International Women's Year in 1975 and the consequent international conference celebrated in Mexico that same year did nothing more than legitimate our concerns and show us that a feminist publication was in effect -as we had thought- a necessity (Urrutia, 1986: 9).

A group of the Mexican Women's Liberation Movement leadership broke off only months after the conference and created the radical collective La Revuelta, which focused solely on producing a magazine of the same name (Biron, 1996). La Revuelta founder Eli Bartra, recalled:

In 1975, after the celebration of International Women's Year under the auspices of the UN, the "Colectivo La Revuelta" was formed as a splinter from the MLM [Movimiento de Liberación de la Mujer]. We decided to create it for basically political reasons (and not because of personal disputes, as has been said). Some of us thought that we should put out a feminist newspaper to reach more women, to bring about what we thought would be a great labor of consciousness-raising (Bartra, 1996: 19).

Finally, the cosmopolitan feminist leadership found a new outlet with liberal interna- 
tional institutions such as the United Nations and the NGO-ization of global feminism, both of which offered important material support for women's activism. This process had started in earnest during the planning and execution of the 1975 conference and marked the shift from the dominance of NGOs that enjoyed consultative status with the UN to a new brand of activist NGOs that drew together activists and resources from around the world to focus on issue-specific programs. Feminist scholars have, for nearly two decades, debated the impact of the NGO "boom" on women's activism, particularly in poorer communities. These debates drew critical attention outside strictly scholarly circles as well. Cecilia Olivares, an editor of the Mexican feminist journal Debate feminista, explains that one of the journal's hottest-selling issues centered on a roundtable about NGO funding, which she describes as "a polemical topic like few others within the [feminist] movement" (Olivares Mansuy, 2004: 77). For a consideration and reconsideration of the $\mathrm{NGO}$-ization of Latin American feminism, see (Alvarez, 2009). The civil-society organizations that stepped forward in response to the 1980s structural-adjustment programs and the 1985 Mexico City earthquake emerged not as a spontaneous irruption of civil society but rather from networks born during the 1975 International Women's Year and nurtured on the leftist politics and cosmopolitan lifestyles of Mexico's feminist activists.

The publication La Correa Feminista exemplifies how these three issues articulated by the 1990s. Started in 1991 by the Mexico City-based Centro de Investigación y Capacitación de la Mujer (CICAM), an organization funded by a feminist NGO connected with Germany's Green Party, the magazine was most closely identified with its principal editor: the Bolivian-born, Chilean-raised, Mexico-adopting lesbian feminist Ximena Bedregal. La Correa grew amid critiques of foreign NGOs' mounting influence over local and regional feminist organizations; by the early 1990s, it had gained regional recognition as one of the most vocal critics of NGO-ization (Rivera López, 2010; see also Biron, 1996). The magazine published trenchant critiques of neoliberalism and capitalist development models, lambasted militarism along with ongoing human-rights abuses (including the Mexican government's response to the 1994 Zapatista uprising), and, above all, the institutionalization of feminism that blunted its critical impact. Perhaps unsurprisingly, by 1998 the editors of La Correa found they could no longer sustain these contradictions. The magazine required external financing that it could not obtain in Mexico, particularly given its pointed critique of the PRI. Although the editors insisted that they remained completely autonomous, they felt that editorial consistency required them to renounce NGO funding; the magazine promptly was dissolved. Bedregal moved her activism on-line and for six years wrote a regular feminist column for La Jornada entitled "Triple Jornada".

In many ways, Bedregal's career (her ridículum vitae, as she calls it) captures IWY's legacies for Mexican feminism -the prominent role of lesbian activists and cosmopolitan intellectuals, the ambivalent embrace of NGOs and antipathy toward the state, and the efforts to commandeer mass media to feminist ends. But the La Correa Feminista also illustrated the ways that feminist movements never escaped their geopolitical context. Much as Echeverría sought a place on the world stage, casting Mexico in the role of the leading Third Worldist man battling the imperialist villains, Carlos Salinas de Gortari -eying the leadership of the World Trade Organization rather than the United Nations- reprised Mexico's role, playing it this time as a neoliberal free-trader, offering NAFTA in lieu of the Carta Echeverría. Similarly, Mexican civil society -the heroines of the 1970 s performance bravely struggling against a repressive regime- by the 1990s found themselves cast as the handmaiden of neoliberalism that helped to usher in the policies of structural adjustment, even as feminist efforts from neighborhood organizations to transnational networks forged 
thoroughgoing critiques of neoliberal policies, continuing to use the United Nations as both foil and ally.

\section{References}

\section{Archival Material}

AGN (Archivo General de la Nación) (w.d.), "Colecciones Particulares", Grupo Clementina Batalla de Bassols, Vol. 2, Exp. 9, Fs. 31-32.

AGN (Archivo General de la Nación) (1975a), "Letter from Lic. Mario Moya Palencia", October 26, Dirección Federal de Seguridad (DFS), Exp. 44-1-74, Leg. 5, pp. 241-242.

AGN (Archivo General de la Nación) (1975b), Dirección Federal de Seguridad (DFS), Vol. 9-342-75, Exp. 5.

AGN (Archivo General de la Nación) (1975c), "Conferencia Mundial del Año Internacional de la Mujer", June 25, DFS, Exp. 9-342-75, Leg. 7, pp. 83-88.

AGN (Archivo General de la Nación) (1975d), "Investigaciones Políticas y Sociales (IPS) report", June 19, Caja 1163-A, Vol. 1, pp. 159-165.

AGN (Archivo General de la Nación) (1975e), "Conferencia Mundial del Año Internacional de la Mujer", June 25, DFS, Exp. 9-342-75, Leg. 7, pp. 155-160.

AGN (Archivo General de la Nación) (1975f), "Investigaciones Políticas y Sociales (IPS) report”, June 29, Caja 1163-A, Vol. 1, pp. 579-586.

AGN (Archivo General de la Nación) (1975g), "Investigaciones Políticas y Sociales (IPS) report", June 24, Caja 1163-A, Vol. 1, pp. 370-371.

AGN (Archivo General de la Nación) (1975h), "Investigaciones Políticas y Sociales (IPS) report", June 27, Caja 1163-A, Vol. 1, pp. 520-552.
AGN (Archivo General de la Nación) (1975i), "Investigaciones Políticas y Sociales (IPS) report", June 29, Caja 1163-A, Vol. 1, pp. 587-590.

AGN (Archivo General de la Nación) (1975j), "Investigaciones Políticas y Sociales (IPS) report”, July 2, Exp. 100-10-1-75, Leg. 53, p. 269.

Arthur and Elizabeth Schlesinger Library on the History of Women (1975), "Lucile K.S. Longview Papers", Box 2, Folder 2.

Elizabeth Reid papers, Australian National University, folder 87.

Intelligence Memorandum Prepared in the Central Intelligence Agency (1975), "Foreign Relations of the United States, 1969-76", Vol. E-14, Part I, Doc. 20, Washington, February 11.

Lane, Bettye (w.d.), "Mexican women demonstrate for family planning information", Bettye Lane Photo Collection, David M. Rubenstein Rare Book and Manuscript Library, Durham, Duke University.

\section{Bibliography}

Acevedo, Marta (2000), "Salario por trabajo doméstico", Debate Feminista, 22, Mexico City, UNAM-Centro de Investigaciones y Estudios de Género, pp. 62-75.

Alvarez, Sonia E. (2009), "Beyond NGO-ization? Reflections from Latin America", Development, 52, Rome, Society for International Development, pp. 175-84.

Anonymous (1975a), "Lib in a land of macho", Newsweek, July 7, New York, Enveritas Group, p. 28.

Anonymous (1975b), "Declaración del presidente Echeverría", México75: Año Internacional de la Mujer, 1 (1), January, Mexico City, p. 1.

Anonymous (1975c), "Interrumpieron el Acto 200 Mujeres", Excélsior, June 20, Mexico City, Cooperativa Excélsior, pp. 1-A, 20-A. 
Anonymous (1975d), "Editorial", El Universal, June 24, Mexico City, Compañía Periodística Nacional, S.A. de C.V., p. 5.

Anonymous (1975e), "Editorial", Excélsior, June 19, Mexico City, Cooperativa Excélsior, p. 6-A.

Anonymous (1975f), "Armó la gorda", Novedades, June 24, Mexico City, OFAVI S.A. de C.V., p. 12.

Anonymous (1975g), "Consideran Como Manipulación el que se Otorgue a la Mujer un año", El Universal, June 30, Mexico City, Compañía Periodística Nacional, S.A. de C.V., p. 10.

Bartra, Eli (1996), "El colectivo La Revuelta o de cuando las brujas conspiraron", fem, 20 (163), Mexico City, pp. 19-21.

Berdejo, Aurora (1975), "El Cambio de la Mujer Tiene que ir Acompañado del Cambio del Varón", El Universal, June 21, Mexico City, Compañía Periodística Nacional, S.A. de C.V., p. 10.

Biron, Rebecca E. (1996), "Feminist Periodicals and Political Crisis in Mexico: fem, Debate Feminista, and La Correa Feminista in the 1990s", Feminist studies, 22, College Park, University of Maryland, pp. 151-69.

Brito de Martí, Esperanza (1996), "De ingenuas modositas y luchadoras bravías", fem, 163, Mexico City, pp. 15-18.

Bueno, Miguel (1975), "Las Mujeres Emasculadoras", El Universal, June 25, Mexico City, Compañía Periodística Nacional, S.A. de C.V., p. 4.

Bunch, Charlotte and Frances Doughty (1975), "IWY - feminist strategy for Mexico City", off our backs, 5 (5), Arlington, off our backs, p. 6.

Carrillo (1975), "Ideas Modernas", El Universal, June 24, Mexico City, Compañía Periodística Nacional, S.A. de C.V., p. 5.

Castañeda, Luis M. (2014), Spectacular Mexico: Design, Propaganda, and the 1968
Olympics, Minneapolis, University of Minnesota Press.

Caulier, Mathieu (2014), De la population au genre: philanthropie, ONG et biopolitiques dans la globalisation, Paris, Editions L'Harmattan.

Cedillo, Adela and Fernando Calderón (eds.) (2012), Challenging Authoritarianism in Mexico: Revolutionary Struggles and the Dirty War, 1964-1982, New York, Routledge.

Collectif de femmes d'Amérique latine et de la Caraïbe (1977), Des latino-américaines, Paris, des femmes, pp. 83-99.

Connelly, Matthew (2008), Fatal Misconception: The Struggle to Control World Population, Cambridge, Harvard University Press.

Davis, Diane E. (1994), Urban Leviathan: Mexico City in the Twentieth Century, Philadelphia, Temple University Press.

Doughty, Frances (1978), "Lesbians and International Women's Year: A Report on Three Conferences", in Ginny Vida (ed.), Our Right to Love: A Lesbian Resource Book, Englewood Cliffs, Prentice-Hall.

Friedan, Betty (1998), "Scary Doings in Mexico City" in It Changed My Life: Writings on the Women's Movement, Cambridge, Harvard University Press.

Fuentes, Pamela (2014), "Entre reivindicaciones sexuales y reclamos de justicia económica: divisiones políticas e ideológicas durante la Conferencia Mundial del Año Internacional de la Mujer. México, 1975", Secuencia, 89, Mexico City, Instituto de Investigaciones Dr. José María Luis Mora", pp. 165-192, <https://bit. ly/355ZMCM>, January 18, 2022.

Greer, Germaine (1986), "World Conference, United Nations' International Women's Year (1975)" in The Madwoman's Underclothes: Essays and Other Writings, New York, Atlantic Monthly Press.

Hinojosa, Claudia (2001), "Gritos y susurros: Una historia sobre la presencia pública 
de las feministas lesbianas", Desacatos, 6. Mexico City, Centro de Investigaciones y Estudios Superiores en Antropología Social, pp. 177-86.

Hiriart, Berta (2002), "Reflexión a dos voces sobre el devenir del feminismo" in Griselda Gutiérrez Castañeda (ed.), Feminismo en México: Revisión histórico-crítica del siglo que termina, Mexico City, Universidad Nacional Autónoma de México, pp. 55-63.

Illades, Carlos (2013), La inteligencia rebelde: la izquierda en el debate público en México, 1968-1989, Mexico City, Océano.

Iracheta, Sergio (1975), "Con el Machismo por Dentro", El Universal, June 22, Mexico City, Compañía Periodística Nacional, S.A. de C.V., p. 13.

Klemesrud, Judy (1975a), "Scrappy, Unofficial Women's Parley Sets Pace", New York Times, June 29, New York, The New York Times Company, p. 2.

Klemesrud, Judy (1975b), "Americans Ease Stand At Women's Conference", New York Times, June 25, New York, The New York Times Company, p. 7, <https://cutt.ly/AIRB2VP>, January 18, 2022

Lamas, Marta (1996), "Mis diez primeros años: el MAS y el MLM", fem, (163), Mexico City, pp. 8-14.

Lamas, Marta (2002), "Fragmentos de una autocrítica" in Griselda Gutiérrez Castañeda (ed.), Feminismo en México: Revisión histórico-crítica del siglo que termina, Mexico City, Universidad Nacional Autónoma de México, pp. 71-83.

Larguía, Isabel (1972), "Contra el trabajo invisible." In Christiane Rochefort (ed.), La liberación de la mujer: año cero, Buenos Aires, Granica, pp. 177-200.

Lau Jaiven, Ana (1987), La nueva ola del feminismo en México: Conciencia y acción de la lucha de mujeres, Mexico City, Editorial Planta.
Lau Jaiven, Ana (2000), "El nuevo movimiento feminista mexicano a fines del milenio" in Eli Bartra, Anna M. Fernández Poncela and Ana Lau Jaiven (eds.), Feminismo en México, ayer y hoy, Mexico City, Universidad Autónoma Metropolitana.

Lau Jaivén, Ana (2014), "La Unión Nacional de Mujeres Mexicanas entre el comunismo y el feminismo: Una difícil relación", La ventana. Revista de estudios de género, 5, Guadalajara, Universidad de Guadalajara, pp. 165-85.

López Vega, Dulce María (2011), "Cuarenta años de feminismo", Debate Feminista, 44, Mexico City, UNAM-Centro de Investigaciones y Estudios de Género, pp. 250-253, <https://cutt.ly/NIR8jLO>, January 18, 2022.

Ludec, Nathalie (1999), "México: Mujeres hacia la emancipación y la afirmación" in Roland Forgues (ed.), Mujer, creación y problemas de identidad en América Latina, Mérida, Universidad de los Andes.

Marcos, Sylvia (1999), "Twenty-Five Years of Mexican Feminisms", Women's Studies International Forum, 22, Amsterdam, Elsevier, pp. 431-33.

Marino (1975), "Liberación Bajo Control", Excélsior, June 20, Mexico City, Cooperativa Excélsior, p. 6-A.

Meléndez S. Roberto (1975), “'Hermanas, amo a las Mujeres ... soy Lesbiana,' Dijo una Feminista", El Heraldo, June 21, Mexico City, Grupo Andrade.

Mogrovejo, Norma (2000), Un amor que se atrevió a decir su nombre: la lucha de las lesbianas y su relación con los movimientos homosexual y feminista en América Latina, Mexico City, Centro de Documentación y Archivo Histórico Lésbico (CDAHL).

OAC (Online Archive of California) (1975), "Oahachan [sic] Matriarch-Mexico", Sisters: West Coast Feminist Newspaper, 6 (1), Los Angeles, University of Southern California. 
Olcott, Jocelyn (2012), "Empires of Information: Media Strategies for the 1975 International Women's Year", Journal of women's history, 24, Maryland, Johns Hopkins University Press pp. 24-48.

Olcott, Jocelyn (2017), International Women's Year: The Greatest Consciousness-Raising Event in History, New York, Oxford University Press.

Olivares Mansuy, Cecilia (2004), "Debatiendo sobre el feminismo en México", Revista Estudos Feministas, 12, Florianópolis, Universidade Federal de Santa Catarina, pp.75-79.

Rivera López, Karen Esmeraldo (2010), "La Correa Feminista, red de diffusion del pensamiento feminista autonónomo de las noventa", in Yuderkys Espinosa Miñoso (ed.), Aproximaciones críticas a las prácticas teórico-políticas del femenismo latinoamericano, Buenos Aires, En la Frontera.

Solanas, Valerie (1968), SCUM manifesto, London, Olympia Press.

Tenorio Trillo, Mauricio (2012), I Speak of the City: Mexico City at the Turn of the Twentieth Century. Chicago, The University of Chicago Press.

Toto Gutiérrez, Mireya (2002), "El feminismo en México y su impacto en el discurso jurídico", in Griselda Gutiérrez Castañeda (ed.), Feminismo en México: Revisión histórico-crítica del siglo que termina, Mexico City, Universidad Nacional Autónoma de México.

UN (United Nations) (2019), "World Population Prospects 2019", New York, UN-Department of Economic and Social Affairs, <https://cutt.ly/fIRrjiM>, January 18, 2022.

Urrutia, Elena (1986), “Una publicación feminista: Alaíde Foppa, siempre entre nosotras", fem, (49), Mexico City, pp. 9-10.

Valadez, Leonardo C. (1975), "La Liberación Femenina, Tarea de la Sociedad ", El Universal, June 22, Mexico City, Compañía Periodística Nacional, S.A. de C.V., p. 9.
Walsh, Michaela (2012), Founding a Movement: Women's World Banking, 19751990, New York, Cosimo Books.

Ward, Peter M. (2013 [1981]), "Mexico City", in Pacione, Michael (ed.), Problems and Planning in Third World Cities, New York, Routledge, pp. 28-65.

Wilson, Ara (2002) "The Transnational Geography of Sexual Rights", in Bradley, Mark Philip and Petro, Patrice (eds.), Truth Claims: Representation and Human Rights, New Brunswick, Rutgers University Press.

Yankelevich, Pablo (ed.) (2002), México, país refugio: la experiencia de los exilios en el siglo XX, Mexico City, Plaza y Valdés.

\section{Interviews}

Acevedo, Marta (1971), "Women's Liberation in Mexico", interviewed by Elizabeth Farnsworth, [Pacifica Radio, NACLA's Latin American Report], Los Angeles, November 4.

Hiriart, Berta (2007), "Interview", interviewed by Mathieu Caulier, [oral], Mexico City, February.

Received: November 22, 2021. Accepted: December 16, 2021. Published: February 2, 2022.

\section{Jocelyn Olcott}

Is Professor of History; International Comparative Studies; and Gender, Sexuality, and Feminist Studies at Duke University. Her first book, Revolutionary Women in Postrevolutionary Mexico, explores questions of gender and citizenship in the 1930s. Her second book, International Women's Year: The Greatest Consciousness-Raising Event in History considers the history and legacies of the United Nation's first world conference on women in 1975 in Mexico City (Oxford University Press, 2017). Her current project, a biography of the activist and folksinger 
Concha Michel, a one-time Communist who became an icon of maternalist feminism and a vocal advocate for recognizing the economic importance of subsistence labors, is under contract with Duke University Press. The book follows Michel's life story from the late nineteenth century to the late twentieth to examine the ways that the concept, labor, and policies surrounding "motherhood" articulated with major shifts in political-economic thought. She has also embarked on an international, interdisciplinary project centered on rethinking the value of care labors broadly speaking, including not only dependent and household care but also, for example, environmental, community, cultural, and sexual care. 